Отримано: 09.11.2020 p.

Прорецензовано: 17.11.2020 p.

Прийнято до друку: 20.11.2020 p.

e-mail: violetta.dutchak@ukr.net

DOI: $10.25264 / 2409-6806-2020-31-186-193$
Дутчак В. Засади взаємодії літератури і музичного мистецтва української діаспори упродовж XX - початку XXI ст. Наукові записки Національного університету «Острозька академія». Серія «Історичні науки». Острог, 2020. Вип. 31. С. 186-193.

\title{
Віолетта Дутчак
}

\section{ЗАСАДИ ВЗАСМОДІЇ ЛІТЕРАТУРИ І МУЗИЧНОГО МИСТЕЦТВА УКРАЇНСЬКОЇ ДІАСПОРИ УПРОДОВЖ ХХ - ПОЧАТКУ ХХІ СТ.}

У дослідженні представлено аналіз методологічних засад взаємодії музики та літератури української діаспори періоду XX - початку XXI cm. Зокрема, у статті пропонується приклад аналізу такої взаємодії на прикладі бандурного мистецтва української діаспори. Рівні взаємодії розглянуті на зразках включення до бандурного репертуару обробок різножанрових фольклорних зразків, релігійно-духовної творчості, шевченкіани, творів на вірші українських поетів XIX-XX cm. Окремо аналізуються приклади співпраиі композиторів і поетів (зокрема, Г. Китастого та I. Багряного).

Ключові слова: украӥнська діаспора, музичне мистецттво, бандурне мистецтво, взаємодія музики й літератури, шевченкіана, обробки фольклору, співпрачя композиторів та поетів.

\section{Violetta Dutchak}

\section{PRINCIPLES OF LITERATURE AND MUSICAL ART INTERACTION OF THE UKRAINIAN DIASPORA DURING THE XX - EARLY XXI CENTURY}

The study presents the methodological foundations analysis of the interaction between music and literature of the Ukrainian diaspora in the period of XX-early XXI century. In particular, the article offers an example of analysis of such interaction on the example of Ukrainian diaspora bandura art. Fundamental in the methodological analysis of the art interaction, and in particular literature and music, are the forms of emigrant (diasporic) worldview - conservative (traditional), synthesizing (unifying), and transforming (experimental). They are manifested in various forms of foreign artists' creative activity - editing (restoration) of ancient genres, their modification and metamorphosis. The concept of "meta-art" was used as the main methodological basis for the music and literature interaction analysis, which is aimed at finding mechanisms for a comprehensive analysis of the Ukrainian diaspora art within the historical stages (according to emigration waves) and within the territorial settlements that found its reflection in figurative-thematic, value-aesthetic, genre, stylistic priorities of artists and interpretation of their ideas and meanings. The levels of literature and musical art interaction are considered by the author of the article on the inclusion samples in the bandura repertoire of various genres arrangements of folklore, religious and spiritual creativity, "shevchenkiana", and works based on the Ukrainian poems of the $X I X-X X$ centuries. Among the musical and folklore samples are epos (dumas, historical songs), domestic, humorous, lyrical songs, and the latest genres of works of the liberation struggle - songs of Sich riflemen, rebel songs. Among the spiritual and religious works are psalms and chants, kolyadkas and shchedrivkas, as well as religious and liturgical compositions by D. Bortnyansky, A. Hnatyshyn, M. Haivoronsky, M. Lysenko, D. Sichynsky, and other works arranged for bandura ensembles or chapels. Shevchenkiana bandura repertoire includes arrangements of folk songs and author's works based on T. Shevchenko's poems for solo bandura players and ensembles, recorded in music editions and sound recordings.

Examples of cooperation between composers and poets in bandura art (in particular, H. Kytasty and I. Bahriany) are analyzed separately.

Key words: Ukrainian diaspora, music art, bandura art, interaction of music and literature, "Shevchenkiana", folklore processing, cooperation of composers and poets.

На сьогодні більшість наукових напрацювань стосовно культури і мистецтва української діаспори у іiі територіальному і часовому розмаїтті передбачають диференційований фаховий підхід, спрямований на аналіз окремих видів мистецтва та жанрових зразків, що засвідчується багатьма науковими роботами - статтями, дисертаціями, монографіями, покажчиками і альбомами тощо. 
Проте актуальним залишається узагальнення міжвидових мистецьких зв'язків, формування інтегральної площини функціонування мистецтва української діаспори в історичній динаміці національної культури упродовж XX століття і до сьогодні [21, с. 26]. Взаємодія різних видів мистецтва, спільна історична динаміка їх розвитку та стильова еволюція, єдність образно-тематичних пошуків митців, особливо в середовищі української діаспори потребують їх розгляду в цілісному системнофункціональному розгортанні. Найдавнішим за походженням $€$ взаємозв'язок музики й літератури, який набуває особливого національно-ментального характеру в умовах формування діаспорних осередків як результату основних еміграційних хвиль з України.

Мистецтво становить особливий вид духовно-творчої діяльності людини, а його види (візуальнопросторові, часові та візуально-часові) засвідчують певну систему взаємозв'язків та взаємовпливів. Оскільки література - універсальний вид мистецтва, то ії взаємодія з іншими видами - живописом, скульптурою, музикою, архітектурою, театром, кіномистецтвом та ін., найбільш виразна за тематичними, жанровими, стильовими та символічно-смисловими рівнями.

Особливими площинами взаємодії літератури та музичного мистецтва є жанрово-видовий, стилістичний, фольклорний, авторський (вірші українських поетів XIX - XXст. Т. Шевченка, I. Франка, Лесі Українки; тексти українських авторів XX ст. - І. Багряного, Б. Лепкого, О. Олеся, ін.), образнотематичний, національно-мітологічний, архетипний, концептуальний, аксіологічний (ціннісний) та ін., кожен із яких може стати основою для окремого вектору дослідження.

У дослідженні буття української еміграції упродовж XX століття пріоритетним стало визначення iii здобутків у контексті нового наукового напряму діаспорознавства (діаспоріани). Якщо спершу більшість досліджень цього нового вектору стосувалися історії, політології, міжнародних відносин, соціології, то пізніше вони починають охоплювати більш конкретні сфери - мовознавство, літературознавство, окремі напрями мистецтвознавства (архітектуру, образотворче і декоративно-ужиткове мистецтво, музичне мистецтво, фольклор) [6, с. 56].

На противагу суто мистецтвознавчим, філософські й історично-культурологічні дослідження українських вчених О. Афоніної [1], В. Корнієнка [9], Н. Кривди [10], Г. Макаренка [13], С. Маценки [14], О. Яковлєва та В. Шульгіної [20] та ін., пропонують узагальнений розгляд культуротворчих процесів, розгляд мистецького процесу в контексті соціокультурної динаміки, що може слугувати певним прототипом системного дослідження і щодо таких процесів у середовищі української діаспори. Спроби комплексного аналізу взаємодії різних видів мистецтва, і зокрема, у середовищі української діаспори, сьогодні представлені в роботах багатьох прикарпатських вчених, зокрема Л. Дуди [2], І. Дундяк [3], В. Дутчак [4-7; 21], Г. Карась [8], Н. Кукурузи [11], Л. Курбанової [12]), О. Слоньовської [15; 16], Б. Тимківа [17], Н. Федорняк [18] та ін. Вищезгадані праці узагальнюють історично-стильові тенденції, творчий доробок окремих митців та мистецьких груп (колективів), пропонують нові синтезовані методологічні принципи аналізу мистецької й літературної творчості 3 урахуванням збереження і трансформації традицій національного мистецтва, торкаються й окремих компаративних аспектів функціонування різних видів мистецтва в іноетнічному середовищі країн поселення українців у світі [21, с. 28].

Метою статті є обгрунтування специфіки взаємодії музики та літератури в середовищі української діаспори упродовж XX - початку XXI ст. Окрім визначення загальних методологічних засад такої взаємодії, конкретизація представлена на прикладі функціонування бандурного мистецтва як напряму, що повною мірою репрезентує і фольклорні зразки, і композиторську творчість на вірші українських поетів.

Жанрово-стильовий і образно-тематичний рівні взаємодії літератури і музики в українській культурі як материкової, так і діаспорної України, проявляються на утворенні міжвидових зв'язків між епосом (прозою), лірикою (поезією), драмою - як основних видів літератури, що втілюються в різноманітних музичних жанрах - опери, оперети, кантати, ораторії, солоспівів (романсів, пісень), хорових композицій, вокальних чи хорових циклів, музично-драматичних вистав, літературно-музичних композицій, синтезованих концертних форм та ін.

Фольклорний рівень взаємодії літератури і музики в середовищі української діаспори визначається взаємодією фольклорних текстів, фольклорних (казкових та мітологічних) образів, обрядових сюжетів та тем, що знайшли своє відображення у зразках музичного автентичного фольклору (зокрема, емігрантських і заробітчанських пісень), музичного фольклоризму (вторинного, реконструйованого фольклору), композиторських обробок та аранжуванні фольклорних зразків, сценічного (концерт- 
ного) і фестивального представлення зразків музичного фольклору (автентичного і опрацьованого). Н. Федорняк зазначає, що «музичний фольклор може функціонувати як органічний елемент сільського побуту у його автентичній формі, а також як його вторинна форма - фольклоризм, в усіляких обробках, у сценічній виконавській практиці та композиторських трансформаціях» [18, с. 45].

Засадничими у методологічному аналізі взаємодії мистецтв, а зокрема літератури та музики, постають форми емігрантського (діаспорного) світогляду - консервуюча (традиційна), синтезуюча (об’єднуюча), трансформуюча (експериментальна) [4, с. 333]. Вони проявляються й у різних формах творчої діяльності митців зарубіжжя - редакція (реставрація) старовинних жанрів, їх модифікація та метаморфоза.

Основним методологічним підгрунтям аналізу взаємодії музики і літератури пропонується використання концепту «метамистецтво», що полягає у пошуку механізмів для комплексного аналізу функціонування мистецтва української діаспори в межах як історичних етапів (відповідно до еміграційних хвиль), так і в територіальних рамках країн поселення, що знайшла відображення у образно-тематичних, ціннісно-естетичних, жанрових, стильових пріоритетах митців та інтерпретації їхніх ідей та смислів [21, с. 32].

Метамистецтво (від англ. metafiction) - твір, найважливішим предметом якого $є$ сам процес його розгортання, дослідження природи твору. Проте, в науковій літературі, зокрема в літературознавстві, зустрічаються й інші інтерпретації цього терміну - як мистецтво про мистецтво або метамодернізм. Поняття «метамистецтво» неодноразово застосовувалося в сучасному мистецтвознавстві та літературознавстві. Так, Світлана Маценка в монографії «Метамистецтво» [14] розглядає теоретичні проблеми термінотворення на межі літератури й музики, зокрема аналізує проблеми взаємодії мистецтв, їх спорідненості, інтеграції, пропонує своєрідний коментар до своєї попередньої монографії «Партитура роману». «Світлана Маценка не просто використовує альтернативні поняття для означення явищ, які традиційно пов'язують із категорією «синтезу мистецтв», а дає змогу осягнути феномен мистецтва зсередини, вийти за межі будь-яких пояснень і розумінь - проникнути в унікальну метасферу, де водночас співіснують і наші зворушені почуття, і збуджений розум» [19].

Термін «метамистецтво» дозволяє обгрунтувати внутрішню взаємодію різних видів мистецтва, зокрема музики й літератури, що базуються на спільних світоглядних, ментальних, націєідентифікаційних засадах, які особливо проявилися саме в середовищі української діаспори. Яскравим прикладом такої органічної взаємодії постає бандурне мистецтво, оскільки саме в ньому спостерігаються як вербальні (мовленнєві) символи, так і музичні (інтонаційні, ладові), що доповнюються символами матеріальними - самими інструментами (кобза/бандура) та духовними - традиціями кобзарства, що становлять філософську основу для функціонування світового бандурного мистецтва [5].

Основними напрямами взаємодії мистецтва бандурної музики (співу, гри) і мистецтва літератури (слова) є, першочергово, площина різнохарактерних фольклорних жанрів, шевченкіана, різностильова творчість композиторів на вірші українських поетів XIX-XX ст.

Упродовж усього часу розвитку бандури в діаспорі завжди залишалися популярними в бандурній виконавській творчості музично-фольклорні зразки - від епічних дум, історичних пісень до побутових, жартівливих, ліричних пісень, новітніх пісень визвольної боротьби - пісень січових стрільців, повстанських пісень, оскільки їх слово несло не лише тематичне, але й смислове навантаження, певну місію проповідування ідеї боротьби, волі, незалежності [7].

Також окремою виступає площина духовного бандурного репертуару, що представлена традиційною для кобзарства паралітургійною творчістю - псальмами й кантами, колядками й щедрівками, а також аранжованою для ансамблів чи капел бандуристів множиною реліzійно-літургійних mворів - Д. Бортнянського, А. Веделя, М. Гайворонського, А. Гнатишина, О. Кошиця, Г. Китастого, М. Лисенка, К. Стеценка, Д. Січинського та ін. - жанрів, які впродовж довгого часу в Радянській Україні були під забороною, натомість в середовищі діаспори отримали не лише розвиток, але й особливу сакрально-символічну місію.

Шевченкіана в репертуарі бандуристів постійно становила невід'ємну (поряд 3 епосом, народною піснею) й актуальну (ідеологічну, суспільно-політичну, патріотичну) складову. Слово поета стало для української нації виразником іiї духовності, іï прагнень та ідеалів, іiї віри у своє майбутнє. Шевченкове слово уособлювало національну самоідентифікацію, розуміння й усвідомлення власної етнічної приналежності. Саме тому поезія Т. Шевченка своє особливе наповнення отримала в музичній інтерпретації представниками української еміграції, української діаспори, у т. ч. і бандуристами. 
Шевченкіана зафіксована у виконавстві бандуристів зарубіжжя порівняно жанрово широко - у сольному (М. Теліга, В. Луців, Б. Шарко, В. Мота) та колективному (Капела бандуристів ім. Тараса Шевченка, Канадська Капела бандуристів, численні ансамблі) варіантах.

Сольна шевченкіана знайшла своє гідне місце в репертуарі співаків-бандуристів українського зарубіжжя. Серед них - бандурист Володимир Луців (Лондон, Великобританія). В. Луців у своїх музичних уподобаннях опирався на класично-академічний стиль, який вміло поєднав з національними музичними традиціями. Шевченкіану В. Луціва репрезентують «Невольник» (муз. А. Голуб), «Встає хмара 3-за лиману» (муз. В. Смця), «Бандуристе, орле, сизий» (музика народна), «Думи мої» (музика народна), «Гетьмани» (музика М. Лисенка) та ін. [4, с. 301].

Володимир Мота (Монреаль, Канада) - також автор обробок та аранжувань для бандури. Виконавська творчість співака-бандуриста зафіксована на двох компакт-дисках: «Бандурист» (2006) i «Твори Т. Шевченка в піснях» (2011), що присвячений 150-й річниці смерті Т. Шевченка. Диск «Бандурист» містить декілька шевченкових творів («Реве та стогне Дніпр широкий», «Над річкою в чистім полі», «Вітер віє, повіває»), а «Шевченківський» альбом охоплює відомі вірші поета, що стали предметом музичної обробки українських композиторів та народної творчості. Це, зокрема, композиції «Заповіт» і «Встає хмара з-за лиману» К. Стеценка, «Реве та стогне Дніпр широкий» Д. Крижанівського, «Три шляхи» Я. Степового, «Єсть на світі доля» А. Кос-Анатольського, «Гомоніла Україна» О. Тарнавської, а також мелодії народних пісень, здійснені виконавцем («Зоре моя вечірняя», «Плавай, плавай, лебедонько», «На розпутті кобзар сидить», «Вітер віє, повіває», «Тече вода в синє море», «Думи мої» та ін.). В. Мота пропонує власне прочитання шевченківських текстів крізь призму музики, часом оригінальну інтерпретацію відомих мелодій. Співак застосовує і традиційні для кобзарства речитативні епізоди, підкреслюючи, що в кобзарів слово завжди було домінуючим порівняно з грою [4, с. 305$]$.

3 іменем Шевченка пов'язана і діяльність багатьох солістів та музичних колективів українського зарубіжжя, серед яких Капела бандуристів ім. Т. Шевченка 3 м. Детройт (США). Окрема «місійна роль» Капели бандуристів розпочинається з 1941 року, коли вона відновлює роботу в окупованому фашистами Києві й обирає для себе назву - імені Тараса Шевченка. Ім’я Кобзаря стало символом Капели, а його ідеї - провідними національними постулатами для виконавців. Кардинально змінюється репертуар колективу. До нього входять патріотичні, раніше заборонені радянською цензурою, твори, у т.ч. шевченківські «Встає хмара з-за лиману», «Заповіт» та ін. Перший зі згаданих творів написаний іï засновником Василем Ємцем для капели, що постала 1918 року в Києві за часів гетьманату Павла Скоропадського [4, с. 79-80].

З 1949 р. капела Г. Китастого, що постійно працює в США, місті Детройті, здійснила численні концертні турне, зафіксувала свою творчість у численних аудіозаписах на платівках і касетах. Багатолітній керівник капели Григорій Китастий створив чимало цікавих композицій, серед яких авторська сюїта «Грай, кобзарю» та численні обробки народних пісень на слова Шевченка. «Грай, кобзарю» - це своєрідна вокально-інструментальна сюїта тричастинної форми, в основі якої авторська музика та народні інструментальні танцювальні мелодії. Твір змальовує картину козацького відпочинку поміж військовими подіями, коли на перше місце виходили гуляння, веселощі, танці, що і відображає життєрадісний, веселий характер. Композиція в цілому надзвичайно звукозображальна, містить видовищно-театралізований характер.

Капела також першою повернула із забуття твори Гната Хоткевича на слова Т. Шевченка. Керівник Капели бандуристів імені Т. Шевченка Володимир Колесник, який очолював її у 1984-1996 pp., спрямував всі зусилля на опанування капелянами усіх тонкощів харківського способу гри, що були детально описані Хоткевичем і використані у його мистецькій спадщині. Шедеври Г. Хоткевича, такі як «Байда», «Буря на Чорному морі», «Заповіт», органічно ввійшли до репертуару капели. У першому турі капели бандуристів ім. Т. Шевченка на історичній Батьківщині в 1991 році (під символічною назвою «Ми знов з тобою, Україно») вперше для вітчизняного слухача прозвучали такі твори, як «Заповіт» (на сл. Т. Шевченка), «Корчомка», «Байда», «Невільничий ринок у Кафі», «Буря на Чорному морі» $[4$, с. 316$]$.

Загалом, багата дискографія Капели засвідчує незмінну популярність шевченківської тематики та їі незмінну присутність у репертуарі впродовж багатолітнього функціонування колективу: «Встає хмара» В. Смця, «Гайдамацька пісня» К. Стеценка, «Реве та стогне» Д. Крижанівського, «Заповіт» Г. Хоткевича, «Грай, кобзарю» Г. Китастого, «Сонце гріє» в обробці П. Потапенка та ін. [4, с. 442-458]. 
Також важливо, що окремий збірник освітньої комісії Товариства українських бандуристів 1987 року (упорядники I. Завадівська, I. Махлай) повністю присвячений шевченківській тематиці [4, с. 412]. До нього увійшли композиції К. Стеценка, П. Демуцького, В. Заремби, Л. Ревуцького, Я. Степового, А. Кос-Анатольського, А. Філіпенка, а також обробки бандуристів В. Смця, Г. Китастого, М. Дейчаківського та ін.

Шевченківська тематика стала невід'ємною складовою репертуару Дівочої капели бандуристок (Детройт, США) під керівництвом Петра Потапенка («У тієї Катерини», муз. М. Лисенка, «У перетику ходила», муз. М. Федоріва) [4, с. 413].

1991 року в Торонто (Канада) відомий бандурист і дослідник Віктор Мішалов засновує і очолює Канадську Капелу бандуристів. Репертуар капели, побудований на традиціях українського кобзарства, включає епічні козацькі пісні, псальми, канти, гумористичні твори та сучасні композиції. До репертуару колективу, виданих аудіодисків («Canadian Bandurist Capella»-2004, «Play Kobzar»-2008) входять численні шевченківські твори, зокрема «Грай, кобзарю» (Г. Китастого), «Бандуристе, орле сизий» (в обр. Я. Орлова), «Реве та стогне Дніпр широкий» (в обр. Г. Китастого), «Встає хмара» (В. Смця). Серед тематичних концертів колективу - програма «Слово Тараса» [4, с. 151].

Слід також згадати, що шевченкова поезія надихнула й українського композитора з США Юрія Олійника (н. 1930 р.) на написання рефлексії «До Шевченка: Дума про чорнобильське село» (на слова О. Гай-Головка).

Григорій Китастий - автор як масштабних вокально-інструментальних творів для капели бандуристів, так і мініатюрних віртуозних композицій для соліста-інструменталіста та для голосу 3 бандурою (пісні й думи). Слід відзначити ту незаперечну вартість, яку вона відіграла протягом довгого періоду в українському емігрантському середовищі, сприяючи збереженню національних традицій, будучи культуротворчим чинником, каталізатором багатьох музичних процесів, стимулятором розвитку репертуару бандуристів.

Масштабним за задумом і мистецькою вартістю є твір композитора «Поема про Конотопську битву» на тексти П. Карпенка-Криниці. Ця композиція, що написана для соліста і хору в супроводі бандур, за формою двочастинна та «асиметричнолукова», а за жанром може бути визначена як комбінована, що об’єднує ознаки думи, мадригалу, кантати. Як композитор Китастий зумів у цьому творі синтезувати досягнення як української, так і європейської музики.

Розмаїття творчої спадщини Григорія Китастого засвідчують і нотні публікації, що здійснювалися протягом 80-х років Освітньою комісією для кобзарських таборів, що діяла при Капелі бандуристів імені Т. Шевченка. Наступні видання творів Г. Китастого були здійснені вже в незалежній Україні. У збірнику «Під срібний дзвін бандур» (1993), упорядкованому Петром Потапенком, багаторічним керівником Дівочої капели бандуристок Детройта й диригентом Капели бандуристів імені Т. Шевченка (у 1960-1962рр.), вміщено зразки аранжувань та обробок Григорія Китастого для чоловічого хору в супроводі ансамлю бандур.

Значною подією для бандуристів України та зарубіжжя стала збірка «Вставай, народе» (1996), що охоплює численний вокально-інструментальний доробок Григорія Китастого (солоспіви, хорові твори, композиції для ансамблів бандуристів).

Більшість творів першого розділу (для чоловічої капели бандуристів та мішаного хору в супроводі ансамблю бандур) написані на слова відомого письменника, громадсько-культурного діяча Івана Багряного (1907-1963). Це, зокрема, «Вставай, народе», «Марш Україна», «Пісня про Тютюнника», «Марш української молоді», - композиції героїко-патріотичного, урочисто-закличного характеру. Пісня «Вставай, народе» була особливо популярною в Капелі імені Т. Шевченка, вона часто звучала в концертах, на урочистих зібраннях. Весною 1948 року в Мюнхені, у межах святкувань Тижня української культури, саме цей твір Григорія Китастого на слова Івана Багряного був обраний для спільного виступу Капели бандуристів і хору «Україна», блискучу мистецьку інтерпретацію якого здійснив видатний український диригент Нестор Городовенко (1885-1964). Загалом, вокально-інструментальна творчість Г. Китастого та І. Багряного цілком відповідала ідеї державництва України, національній ідеї, боротьбі за ії утвердження.

Одним 3 яскравих творів Григорія Китастого - «Дума про Симона Петлюру» на слова К. Даниленка-Данилевського, в основі якої кобзарський новотвір відомого харківського бандуриста І. Кучугури-Кучеренка. Твір був записаний 1926 р., а входив він до репертуару кобзарів усієї Лівобережної України. У тексті думи - відгук на смерть видатного українського політичного діяча Симона Петлю- 
ри (1926). Слухачі-очевидці побутування цієї думи в Україні не раз згадували спорідненість твору 3 піснею «На смерть Шевченка» як за змістом, так і за сумовитою протяжною мелодикою. У часи заборон мандрівні виконавці (зокрема, С. Пасюга) часто починали пісню про смерть Т. Шевченка, поступово переходячи на новітній текст про С. Петлюру. 3 кобзарськими думами твір має деякі спільні риси, що проявляються в інтонаціях мелодики (\#IV, \#VI ступені), насичених інструментальних переграх, сольних речитативах, типовому думовому супроводі (тремоляндо, глісандо, імітації мелодичних розспівів).

Не можна оминути ще однієї композиції Г. Китастого - пісні «Грай, кобзарю» на слова Т. Шевченка. Це - своєрідна вокально-інструментальна сюїта тричастинної форми, в основі якої авторська музика та народні інструментальні танцювальні мелодії. Твір змальовує картину козацького відпочинку поміж військовими подіями, коли на перше місце виходили гуляння, веселощі, танці, що й відображає життєрадісний, веселий характер. Композиція, у цілому, надзвичайно звукозображальна, містить видовищно-театралізований характер.

Серед творів першого розділу збірника «Вставай, народе» слід особливу увагу звернути на композиції ностальгічно-ліричного характеру, які давно користуються популярністю в концертних програмах виконавців української діаспори. Серед них пісні на слова О. Підсухи «Як давно» та на слова Н. Калюжної «Нагадай, бандуро, співами» (обидві композиції написані для соліста, хору й капели бандуристів). Другий розділ збірки «Вставай, народе» охоплює вокальні твори в супроводі бандури: «Ой червона калинонько» (сл. О. Ільченка), «Виший, виший» (сл. М. Пироженка), дитячі пісні патріотичного і ліричного характеру «Йдуть дівчатка і хлоп'ятка», «Пошли нам, Боже» (сл. К. Перелісної), «Весна зимою» (сл. О. Ярового).

У творчому вокально-інструментальному доробку Григорія Китастого для бандури спостерігаємо розмаїття тематики, що відображає як картини природи, так і різноманітні емоційно-психологічні стани душі людини. Як щирий патріот Китастий не цурався і лірично-ностальгічних емоцій, співзвучних його життю і творчості.

Взаємодія літератури й музики у мистецтві української діаспори охоплює складний і багатоманітний процес - від ретрансляції традиційних музично-фольклорних жанрів через шевченкіану, як найбільш виразну ідентифікаційну площину духовності нації, іiі прагнень та ідеалів, іiі віри у своє майбутнє, до безпосередньої співпраці композиторів і письменників, музичного втілення літературних текстів. Ці процеси відобразили спільні напрями національного самовизначення митців через сукупні - вербальний (мовний) та інтонаційний (музичний) - ряди. Вони були спрямовані на опоетизування України як бажаної, але далекої й недосяжної Батьківщини; на відображення іiї історичного минулого як засобу збереження національної пам'яті, як підгрунтя боротьби за іiі волю і незалежність; на емоційно-психологічні характеристики людини (сприйняття природи, переживання, втрата, ностальгія).

Бандурне мистецтво діаспори виявляє значні композиторські та виконавські здобутки, зокрема, й на основі взаємодії літературної та музичної площин, що значною мірою уможливило збереження давніх кобзарських традицій та розвиток новаційних засад творчості.

Перспективними напрямами дослідження постає аналіз взаємодії інших видів мистецтва - як музичного (вокального, хорового), так і театрального (літературна композиція, інсценізація) - із літературою, у їх жанровій, стильовій та образо-тематичній диференціації.

\section{Список використаних джерел та літератури:} $314 \mathrm{c}$.

1. Афоніна О. Коди культури і «подвійне кодування» в мистецтві [монографія]. Київ: НАКККіМ, 2017.

2. Дуда Л. Фольклорні жанри та їх трансформація у творчості для бандури: Дис. ... на здобуття канд. мист.: 26.00 .01 - теорія та історія культури (мистецтвознавство) / Прикарпатський національний університет імені Василя Стефаника. Івано-Франківськ, 2016. 289 с.

3. Дундяк I. Українське церковне малярство другої половини XX - початку XXI століть (особливості функціонування, збереження, трансформації та відродження) [монографія]. Івано-Франківськ, 2019. 408с., 40 іл.

4. Дутчак В. Бандурне мистецтво українського зарубіжжя XX - початку XXI століття [монографія]. ІваноФранківськ: Фоліант, 2013. 488 с.+ 72 іл.

5. Дутчак В. Бандурне мистецтво в системі музичної культури української діаспори XX - початку XXI ст. Наукові записки Наџіонального університету «Острозька академія». Серія «Історичні науки» / ред. колегія: І. Пасічник, Л. Винар, А. Атаманенко та ін. Острог: Видавництво Національного університету «Острозька академія», 2015. Вип. 23. С. 175-180. URL: https://histj.oa.edu.ua/assets/files/Dutchak.pdf (дата звернення: 14.09.2020 p.). 
6. Дутчак В. Концепт «метамистецтво» в осмисленні здобутків української діаспори. Музичне мистецтво ХХ століття: історія, теорія, практика: збірник наукових праць інституту музичного мистецтва Дрогобицького педагогічного університету імені Івана Франка / заг. ред. і упоряд. А. Душного. Дрогобич; Кельце; Каунас; Алмати; Баку: Посвіт, 2019. С. 56-63.

7. Дутчак В. Взаємодія музичної та літературної площини мистецтва української діаспори (на прикладі композиторської творчості для бандури). Актуальні проблеми народно-інструментального виконавства в Україні: історія та сучасність: зб. наук. пр. / Рівнен. держ. гуманіт. ун-т, Ін-т мистецтв: редактор-упорядник Л. Горіна. Рівне: Волин. обереги, 2019. С. 54-63.

8. Карась Г. Музична культура української діаспори у світовому часопросторі ХХ століття [монографія]. Івано-Франківськ: Тіповіт, 2012. 1164 с.

9. Корнієнко В. Гуманітарні комунікативні системи як чинники європейської інтеграції. Україна та Франція: кроскультурний діалог: [монографія]. Київ: НАКККіМ, 2016. 432 с.

10. Кривда Н. Українська діаспора: досвід культуротворення [монографія]. Київ: Академія, 2008. 279 с.

11. Кукуруза Н. Жанри і форми літературної композиції у творчості діячів мистецтв української діаспори. Мистецтвознавчі записки: зб. наук. праџь. Київ: Міленіум, 2014. Вип. 25. С. 208-214.

12. Курбанова Л. Різновекторна діяльність Павла Маценка в контексті української музичної культури ХХ століття : дис. ... канд. мист.: 26.00.01 - теорія та історія культури (мистецтвознавство) / Прикарпатський національний університет імені Василя Стефаника. Івано-Франківськ, 2019. 313 с.

13. Макаренко Г. Музика - як метамистецтво в ірраціоналістичній естетиці XIX століття: Автореф. дис... канд. філос. наук: 09.00.08; Київ. нац. ун-т ім. Т. Шевченка. Київ, 2000. 16 с.

14. Маценка С. Метамистецтво [монографія]. Львів: Апріорі, 2017. 120 с.

15. Слоньовська О. Слід невловимого Протея: (міф України в літературі української діаспори 20-х - 50-х років XX століття) [монографія] / наук. ред. М. Ільницький. Вид. 2-ге. Івано-Франківськ: Плай; Коломия: Вік, 2007. $684[2] \mathrm{c}$.

16. Слоньовська О. Ефект амальгами: Міф України в літературі української діаспори 20 - 50x років XX ст. [монографія]. Івано-Франківськ: Місто НВ, 2016. 584 с.

17. Тимків Б. Мистецтво України та діаспори: дереворізьба сакральна й ужиткова [монографія]. ІваноФранківськ: Нова Зоря, 2009. 206 с.

18. Федорняк Н. Трансформація музичної фольклорної традиції у середовищі української діаспори Північної Америки: історико-виконавський аспект : дис. ... канд. мистецтвозн.: 17.00.03 - музичне мистецтво. Львів: ЛНМА, 2020. $316 \mathrm{c}$.

19. Челецька M. Інтермецо про літературу з ідеальним слухом. URL: https://zbruc.eu/node/76291 (дата звернення: 19.09.2020).

20. Яковлев О., Шульгіна В. та ін. Синергетична парадигма простору культури [монографія]. Київ: НАКKKiM, 2014. 400 c.

21. Dutchak V. Methodological principles of complex research of Ukrainian Diaspora Art. Art criticism: challenges of the XXI century: collective monograph / A. Dushniy, V. Dutchak, A. Stashevskyi, M. Strenacikova, etc. Lviv; Toruń: Liha-Pres, 2019. P. 25-45.

\section{References}

1. Afonina O. Kody kultury i «podviine koduvannia» v mystetstvi [monohrafiia]. Kyiv: NAKKKiM, 2017. 314 s.

2. Duda L. Folklorni zhanry ta yikh transformatsiia u tvorchosti dlia bandury: Dys... na zdobuttia kand. myst.: 26.00.01 - teoriia ta istoriia kultury (mystetstvoznavstvo) / Prykarpatskyi natsionalnyi universytet imeni Vasylia Stefanyka. Ivano-Frankivsk, 2016. 289 s.

3. Dundiak I. Ukrainske tserkovne maliarstvo druhoi polovyny XX - pochatku XXI stolit' (osoblyvosti funktsionuvannia, zberezhennia, transformatsii ta vidrodzhennia) [monohrafiia]. Ivano-Frankivsk, 2019. 408 s., 40 il.

4. Dutchak V. Bandurne mystetstvo ukrainskoho zarubizhzhia XX - pochatku XXI stolit' [monohrafiia]. IvanoFrankivsk: Foliant, 2013. 488 s.+ 72 il.

5. Dutchak V. Bandurne mystetstvo v systemi muzychnoi kultury ukrainskoi diaspory XX - pochatku XXI st. Naukovi zapysky Natsionalnoho universytetu "Ostrozka akademiia». Seriia «Istorychni nauky» / red. kolehiia: I. Pasichnyk, L. Wynar, A. Atamanenko ta in. Ostroh: Vydavnytstvo Natsionalnoho universytetu «Ostrozka akademiia», 2015. Vyp. 23. S. 175-180. URL: https://histj.oa.edu.ua/assets/files/Dutchak.pdf (data zvernennia: 14.09.2020 r.).

6. Dutchak V. Kontsept «metamystetstvo» v osmyslenni zdobutkiv ukrainskoi diaspory. Muzychne mystetstvo XX stolittia: istoriia, teoriia, praktyka: zbirnyk naukovykh prats instytutu muzychnoho mystetstva Drohobytskoho pedahohichnoho universytetu imeni Ivana Franka / zah. red. i uporiad. A. Dushnoho. Drohobych; Keltse; Kaunas; Almaty; Baku: Posvit, 2019. S. 56-63.

7. Dutchak V. Vzaiemodiia muzychnoi ta literaturnoi ploshchyny mystetstva ukrainskoi diaspory (na prykladi kompozytorskoi tvorchosti dlia bandury). Aktualni problemy narodno-instrumentalnoho vykonavstva $v$ Ukraini: istoriia ta suchasnist: zb. nauk. pr. / Rivnen. derzh. humanit. un-t, In-t mystetstv: redaktor-uporiadnyk L. Horina. Rivne: Volyn. oberehy, 2019. S. 54-63.

8. Karas H. Muzychna kultura ukrainskoi diaspory u svitovomu chasoprostori XX stolittia [monohrafiia]. IvanoFrankivsk: Tipovit, 2012. $1164 \mathrm{~s}$.

9. Korniienko V. Humanitarni komunikatyvni systemy yak chynnyky yevropeiskoi intehratsii. Ukraina ta Frantsiia: kroskulturnyi dialoh: [monohrafiia]. Kyiv: NAKKKiM, 2016. $432 \mathrm{~s}$.

10. Kryvda N. Ukrainska diaspora: dosvid kulturotvorennia [monohrafiia]. Kyiv: Akademiia, 2008. 279 s.

11. Kukuruza N. Zhanry i formy literaturnoi kompozytsii u tvorchosti diiachiv mystetstv ukrainskoi diaspory. Mystetstvoznavchi zapysky: zb. nauk. prats. Kyiv: Milenium, 2014. Vyp. 25. S. 208-214. 
12. Kurbanova L. Riznovektorna diialnist Pavla Matsenka v konteksti ukrainskoi muzychnoi kultury XX stolittia: dys. ... kand. myst.: 26.00.01 - teoriia ta istoriia kultury (mystetstvoznavstvo) / Prykarpatskyi natsionalnyi universytet imeni Vasylia Stefanyka. Ivano-Frankivsk, 2019. $313 \mathrm{~s}$.

13. Makarenko H. Muzyka - yak metamystetstvo v irratsionalistychnii estetytsi XIX stolittia: Avtoref. dys... kand. filos. nauk: 09.00.08; Kyiv. nats. un-t im. T. Shevchenka. Kyiv, 2000. 16 s.

14. Matsenka S. Metamystetstvo [monohrafiia]. Lviv: Apriori, 2017. $120 \mathrm{~s}$.

15. Sloniovska O. Efekt amalhamy: Mif Ukrainy v literaturi ukrainskoi diaspory $20-50 \mathrm{kh}$ rokiv XX st. [monohrafiia]. Ivano-Frankivsk: Misto NV, 2016. 584 s.

16. Sloniovska O. Slid nevlovymoho Proteia: (mif Ukrainy v literaturi ukrainskoi diaspory $20-\mathrm{kh}-50$-kh rokiv XX stolittia) [monohrafiia] / nauk. red. M. Ilnytskyi. Vyd. 2-he. Ivano-Frankivsk: Plai; Kolomyia: Vik, 2007. 684 [2] s.

17. Tymkiv B. Mystetstvo Ukrainy ta diaspory: derevorizba sakralna y uzhytkova [monohrafiia]. Ivano-Frankivsk: Nova Zoria, 2009. $206 \mathrm{~s}$.

18. Fedorniak N. Transformatsiia muzychnoi folklornoi tradytsii u seredovyshchi ukrainskoi diaspory Pivnichnoi Ameryky: istoryko-vykonavskyi aspekt: dys. ... kand. mystetstvozn.: 17.00.03 - muzychne mystetstvo. Lviv: LNMA, 2020.316 s.

19. Cheletska M. Intermetso pro literaturu z idealnym slukhom. URL: https://zbruc.eu/node/76291 (data zvernennia: 19.09.2020).

20. Iakovlev O., Shulhina V. ta in. Synerhetychna paradyhma prostoru kultury [monohrafiia]. Kyiv: NAKKKiM, 2014. $400 \mathrm{~s}$.

21. Dutchak V. Methodological principles of complex research of Ukrainian Diaspora Art. Art criticism: challenges of the XXI century: collective monograph / A. Dushniy, V. Dutchak, A. Stashevskyi, M. Strenacikova, etc. Lviv; Toruń: Liha-Pres, 2019. P. 25-45. 